
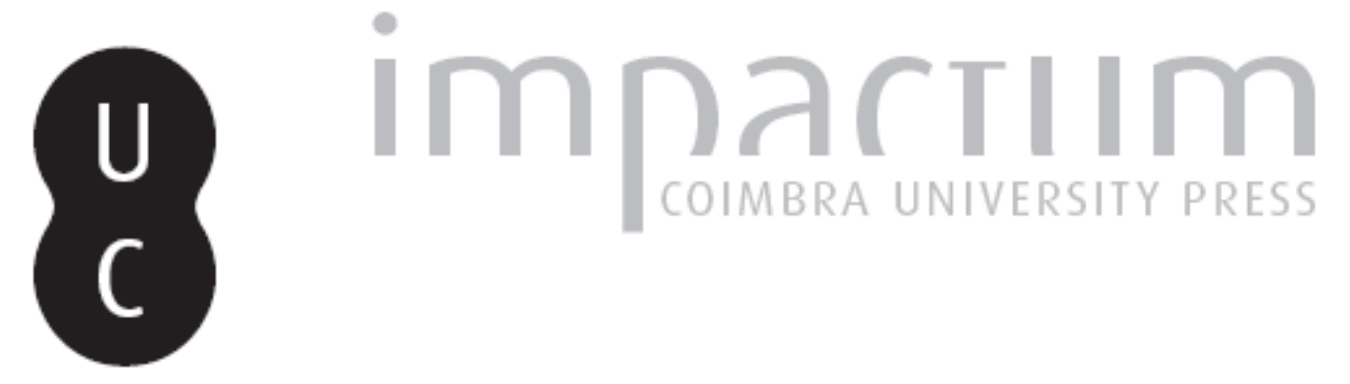

\title{
Cinema e História Antiga: a propósito do filme Cleopatra (1963) de Joseph Leo
} Mankiewichz. I parte
Autor(es):
Sales, José das Candeias
Publicado por: Centro de História da Universidade de Lisboa
URL persistente:
URI:http://hdl.handle.net/10316.2/23781
DOI:
DOI:http://dx.doi.org/10.14195/0871-9527_19_5
Accessed : $\quad$ 26-Apr-2023 13:21:07

A navegação consulta e descarregamento dos títulos inseridos nas Bibliotecas Digitais UC Digitalis, UC Pombalina e UC Impactum, pressupõem a aceitação plena e sem reservas dos Termos e Condições de Uso destas Bibliotecas Digitais, disponíveis em https://digitalis.uc.pt/pt-pt/termos.

Conforme exposto nos referidos Termos e Condições de Uso, o descarregamento de títulos de acesso restrito requer uma licença válida de autorização devendo o utilizador aceder ao(s) documento(s) a partir de um endereço de IP da instituição detentora da supramencionada licença.

Ao utilizador é apenas permitido o descarregamento para uso pessoal, pelo que o emprego do(s) título(s) descarregado(s) para outro fim, designadamente comercial, carece de autorização do respetivo autor ou editor da obra.

Na medida em que todas as obras da UC Digitalis se encontram protegidas pelo Código do Direito de Autor e Direitos Conexos e demais legislação aplicável, toda a cópia, parcial ou total, deste documento, nos casos em que é legalmente admitida, deverá conter ou fazer-se acompanhar por este aviso.

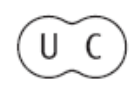



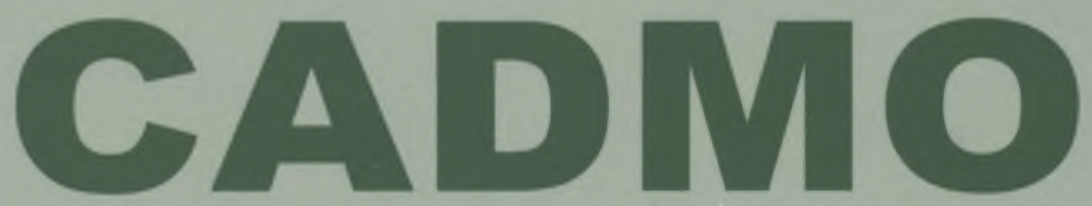

Revista de História Antiga

\author{
Centro de História \\ da Universidade de Lisboa
}

19

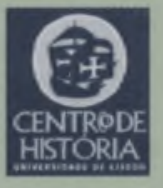

430 =

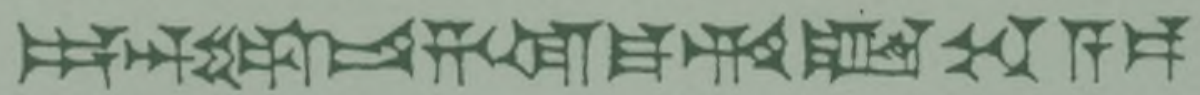

MHNIN AEI $\Delta$ E $\Theta E A ~ \Pi H \Lambda H I A \triangle E \Omega$ 


\title{
CINEMA E HISTÓRIA ANTIGA. \\ A PROPÓSITO DO FILME CLEOPATRA (1963) DE JOSEPH LEO MANKIEWICZ - I PARTE ${ }^{1}$
}

\author{
JOSÉ DAS CANDEIAS SALES \\ Universidade Aberta; Centro de História da Universidade de Lisboa \\ jcsales@clix.pt
}

\begin{abstract}
Resumo
O objecto central da reflexão apresentada é o filme Cleopatra (1963) de Joseph Leo Mankiewicz. Nesta I Parte é efectuada uma explanação teórica sobre as relações entre cinema e história antiga, exemplificada com os casos de algumas produções cinematográficas específicas, e traçada uma panorâmica alargada, desde o final do século XIX até aos 60 do século $X X$, sobre o cinema histórico referente à figura de Cleópatra.
\end{abstract}

Palavras-chave: Cinema; história antiga; Cleópatra.

\begin{abstract}
The Joseph Mankiewicz's film, Cleopatra (1963), is the main object of reflection. In Part I is made a theoretical explanation about the correlation between cinema and ancient history, exemplified by some specific film productions, and is also made an extensive overview since the late nineteenth century up to the sixties in the twenty century about historical films centralized in the figure of Cleopatra.
\end{abstract}

Key words: Cinema; ancient history; Cleopatra. 


\section{Cinema e História Antiga}

As décadas de 50 e de 60 do século XX podem considerar-se os anos dourados dos épicos de cariz histórico centrados na época antiga, seja da Antiguidade pré-clássica seja da Antiguidade clássica. Alguns dos filmes então produzidos figuram entre as obras-primas da sétima arte, tendo alguns deles sido nomeados e mesmo ganho óscares da Academia em várias categorias. Talvez o caso mais paradigmático e conhecido seja o de Ben-Hur (1959), de William Wyler, com os onze óscares que arrecadou, feito sem precedentes até então.

Como já tivemos ocasião de escrever em relação aos épicos bíblicos, a Bíblia como um todo (o Antigo e o Novo Testamento) foi uma importante fonte de inspiração para muitas destas (re)criações cinematográficas. De facto, recriando ou procurando recriar os ambientes e contextos históricos da vida dos antigos Hebreus e demais povos antigos citados na Bíblia ou da vida de Cristo e dos primeiros cristãos e suas comunidades, estes filmes tentaram, através da imagem, uma leitura, raramente crítica porém, dessas antigas épocas e conjunturas ${ }^{(2)}$.

Paralelamente, centrados em figuras históricas de relevo ou em épocas particularmente apelativas para o enquadramento fílmico (nomeadamente no antigo Egipto ou em realidades civilizacionais afins), outros filmes "históricos" foram sendo produzidos por poderosos e dinâmicos estúdios e interpretados por hoje celebrizados actores e actrizes.

Filmados com as técnicas mais recentes ao dispor da indústria cinematográfica, em locais carregados de memória, história ou significado histórico (ex.: Palestina, Sinai, Egipto, Roma, etc.) ou em estúdios especialmente preparados para o efeito, com cenários e guarda-roupas magníficos, sumptuosos e arrebatadores, repletos de atmosferas exóticas e sensuais, com a participação de milhares de figurantes e conhecidos actores e actrizes da cena internacional nos principais papéis, com mais ou menos efeitos especiais, câmaras lentas ou aceleradas e sugestivas e expressivas bandas sonoras, os dramas e as "histórias antigas", com os seus diversos personagens, foram passadas ao cinema e apresentados a milhões de espectadores por todo o mundo.

Estas superproduções, não obstante os seus colossais orçamentos e avançados meios técnicos (croma key, cinerama, cinemascope e technicolor) e artísticos, eram, quase todas, filmes "fáceis de ver» e "fáceis de seguir" (narrativas simples) - componentes maiores de uma eficácia comunicativa que prescindia do conhecimento aprofun- 
dado das fontes históricas -, e funcionavam justamente como sucedâneos ou complementos eficazes da leitura dessas narrativas-base.

Neste sentido, a sétima arte exerceu sempre uma grande atracção pelas longas metragens espectaculares focalizadas, por exemplo, no antigo Egipto, adaptando histórias tradicionais ou romances centrados nessa civilização e nos seus imaginados ambientes. No entanto, na maior parte dos casos, não é dado qualquer destaque efectivo às realizações dos antigos Egípcios. Frequentemente, enfatiza-se o pretenso abuso dos direitos humanos (escravidão, trabalho compulsório, chicotadas, maus-tratos). As suas realizações artísticas são menosprezadas ou perfeitamente laterais e a narrativa fílmica prefere fixar-se na sua ganância por objectos de ouro e bens materiais. O país do Nilo é concebido como um imenso deserto poeirento, onde todas as inovações tecnológicas são oriundas do estrangeiro. O fértil delta do rio nunca é mostrado. O Egipto é, em muitos aspectos, um território agressivo, pagão e maldito.

Entre outros, merece destaque o filme The Egyptian, de 1954, realizado pelo veterano Michael Curtiz, um especialista em westerns, em cinemascope para a $20^{\text {th }}$ Century Fox, baseando-se no romance homónino de Mika Waltari, adaptado por Philip Dunne e Casey Robinson. Com este filme, o fotógrafo Leon Shamroy foi nomeado para o Óscar de 1955.

The Egyptian conta a história de um jovem médico egípcio, Sinuhé, representado por Edmund Pardon depois de a primeira escolha ter sido Marlon Brando que abandonou o projecto. Efectuando estreitos paralelismos com a história bíblica de Moisés, Sinuhé é recolhido das águas do Nilo e adoptado, neste caso por um modesto médico egípcio que desconhece, porém, o seu sangue real. A acção passa-se na XVIII dinastia, na corte de Amenhotep IV (Michael Wilding), o faraó que no ano 5 do seu reinado mudou o nome para Akhenaton. O servo de Sinuhé, Kaptah, que o acompanha nas suas deambulações, é interpretado por Peter Ustinov, para muitos o melhor desempenho artístico neste filme. No meio das intrigas palacianas, intervém também o militar Horemheb (Victor Mature), amigo de Sinuhé, que ascenderá ao trono do Egipto após casar com Baketamon (Gene Tierney), irmã de Akhenaton.

Às boas intenções de Sinuhé, que se torna no brilhante médico do epiléptico faraó, apostado em procurar a verdade na corte amarniana e no templo de Aton, o deus único proclamado pelo faraó para desgosto dos irados sacerdotes politeístas, opõe-se uma sedutora babilónica de nome egípcio, Nefer, interpretada por Bella Darvi, que o tenta separar, 


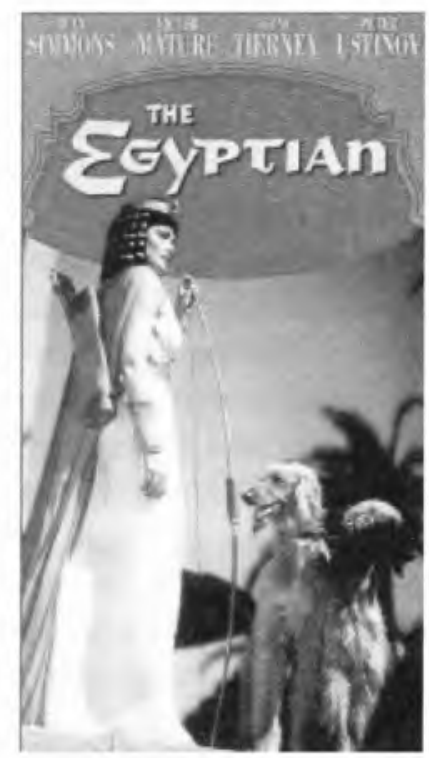

a todo o custo, da abnegada e monoteísta Merit (Jean Simmons). Com a morte desta, o revoltado Sinuhé, que atribui a culpa às ideias religiosas e a Aton, o deus do faraó, acaba por se aliar a Horemheb e envenena Akhenaton.

Neste filme, historicamente passado no Império Novo/final da XVIII dinastia da história egípcia, verifica-se uma consistente preocupação de recriação dos interiores egípcios, através do cuidado posto na decoração das paredes, no mobiliário, na estatuária, na baixela, além da atenção conferida ao vestuário, joalharia, coroas, adereços de adorno pessoal, etc.

No ano seguinte, em 1955, produzido pela Continental Company Ltd., Howard Hawks, na altura já autor de dois grandes westerns - Red River (1948) e The Big Sky $(1952)^{(3)}$-, roda no Egipto e nos estúdios Titanus em Roma o épico em cinemascope Land of the Pharaohs para a Warner Bros, com guião de Harold Jack Bloom, Harry Kurnitz e William Faulkner e música de Dimitri Tiomkin. Narra a história da construção da Grande Pirâmide de Guiza, mandada erguer pelo faraó Khufu, por volta do século XXVI a. C., durante a IV dinastia, Império Antigo.

No filme, o faraó (Jack Hawkins) está obcecado com a aquisição de toda a riqueza material possível para a levar para o Além. É assim que aceita o projecto de Vashtar (James Robertson Justice), um arquitecto, cujo povo (os Kuchitas) é escravizado pelo faraó, de lhe construir um túmulo inexpugnável em troca da liberdade do seu povo. Face à megalomania e indigna crueldade do faraó, James Robertson Justice tem um simpático desempenho que torna a sua personagem a mais atraente e agradável para os espectadores. Há claros ecos da história bíblica da servidão dos Hebreus no Egipto, embora historicamente noutra época bem distinta da época das pirâmides ${ }^{(4)}$. Durante a construção, em troca do pagamento do imposto fixado para Chipre, o faraó casa com uma princesa cipriota, Nellifer (Joan Collin, então com 22 anos), que se torna a sua segunda esposa que acabará por conspirar contra ele, seduzindo o guarda do tesouro, para o privar de levar o seu tesouro para a "segunda vida" e para se tornar a rainha do Egipto, reservando para si toda a riqueza acumulada. 
Embora construído essencialmente pela dimensão do entretenimento, com milhares de figurantes-trabalhadores da pirâmide (9787 numa só cena) e com o colorido guarda-roupa dos cortesãos egípcios, o filme comporta "despidos" e incoerentes cenários de interiores, cenas e diálogos desnecessários e ridículos que levaram inclusive a que o realizador e os actores principais tivessem depois, ao longo dos anos, criticado o filme. O próprio realizador sintetizava as suas dificuldades e reticências quando dizia: "I don't know how a pharaoh talks."

Sem desenhar claramente as concepções judaicas e cristãs, Land of the Pharaohs apresenta um racional Vashtar que não acredita na vida após a morte. O filme não promove, assim, os valores bíblicos. Como escravos do Egipto, os Kuchitas cumprem a mesma função narrativa dos Hebreus bíblicos. Neste sentido, Vashtar é um Moisés libertador.

Ao contrário de The Egyptian, que fazia de um egípcio o herói, Land of the Pharaohs fazia dos estrangeiros os verdadeiros heróis. Uma interessante curiosidade relacionada com este filme foi o facto de as autoridades egípcias da época terem proibido a sua exibição com o argumento de que o enredo sugeria que os Judeus haviam construído a Grande Pirâmide.

Nefertite, Regina del Nilo, outro filme com características semeIhantes a Sinuhé, o Egípcio, foi rodado em Itália em 1961 sob a batuta do realizador italiano Fernando Cerchio. Produzido por Ottavio Poggi, o guião era da autoria conjunta de John Byrne, Fernando Cerchio e
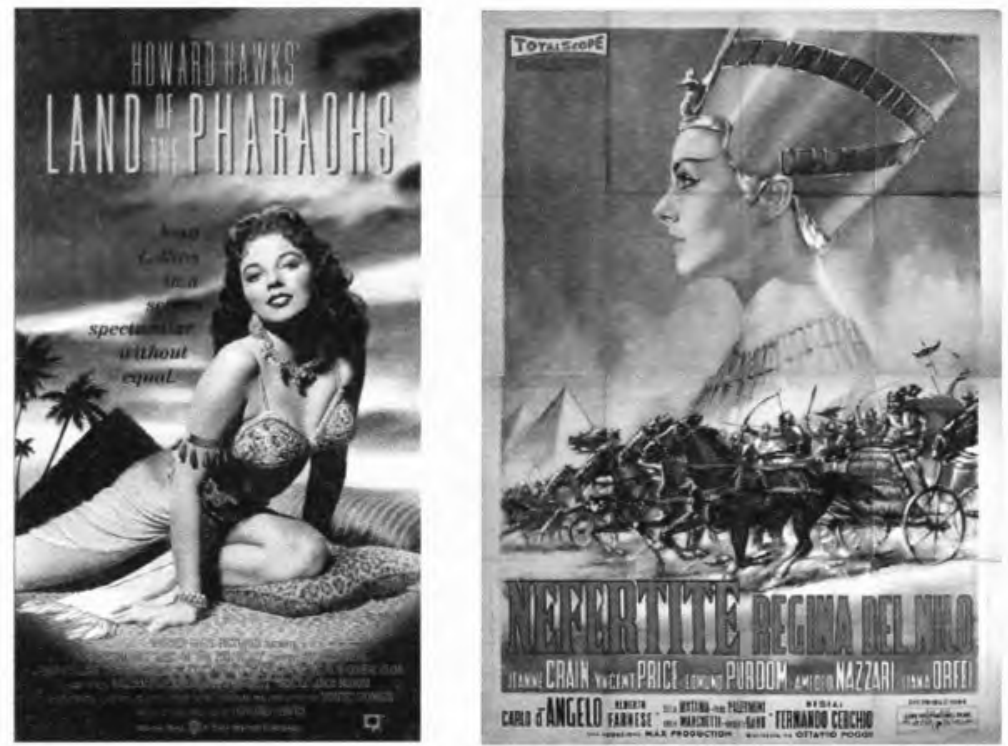
Ottavio Poggi. O filme, numa livre reconstituição histórica, narra a história da rainha do Egipto Nefertiti (Jeanne Crain), a bela e misteriosa esposa do faraó Amenhotep IV/Akhenaton (Amedeo Nazzari). Vincent Price (um credível sacerdote de Amon-Ré, de nome Benakon) e Edmund Purdom (o escultor Tumos, uma corruptela do histórico escultor Tutmés, que realizou o célebre busto da rainha amarniana) integram também o elenco. A indumentária dos actores é extraordinária.

A história é muito simples e dada a uma certa especulação face aos conhecimentos então existentes sobre as personagens amarnianas: o escultor Tumos, enamorado pela sua rainha, ainda antes dela subir ao estatuto de esposa real, vê-a assumir um casamento forçado pelo pai com Amenhotep IV. É a típica história dos amores contrariados em nome dos interesses políticos e sociais. Neste caso, o drama romântico é contraposto à revolução de Amarna. Os amantes, no meio de um ambiente adverso, permanecem fiéis aos seus sentimentos e agem em conformidade. Tumos auxiliará Nefertiti a recrutar um exército e a ocupar o poder como rainha-faraó após o suicídio do rei. No final, assassina o pai de Nefertiti, vingando-se assim daquele que o afastou da sua amada.

Em 1965, o polaco Jerzy Kawalerowicz, apesar do modesto orçamento, realiza, num ambicioso projecto que é filmado em technicolor e em cinemascope, o melhor filme do género, intitulado Pharaoh, escolhendo desta feita para cenário a época de transição dos reinados de Ramsés

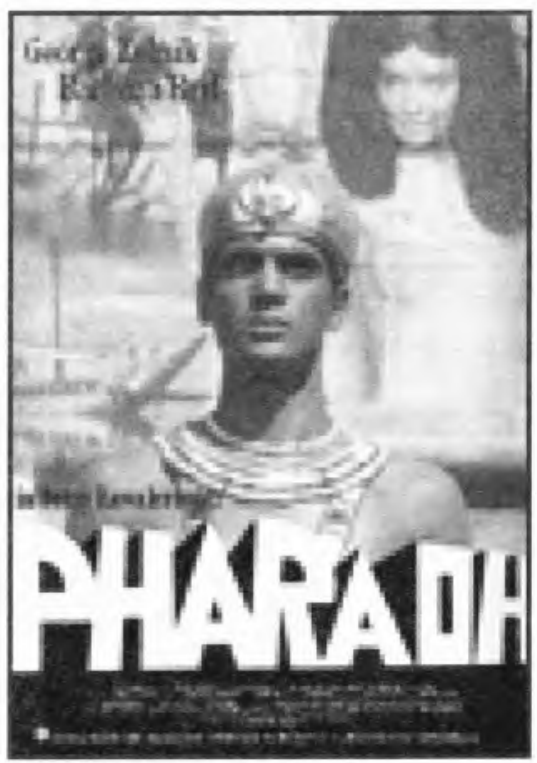
XII e de Ramsés XIII (Jerzy Zelnik), no final da XX dinastia, faraós historicamente inexistentes.

Com um guião assinado pelo próprio Kawalerowicz e por Tadeusz Konwicki, o filme narra a progressiva deteriorização do Estado egípcio. A este do Egipto sente-se já o crescimento do poderoso reino, depois império, dos Assírios, que acabará, aliás, por invadir e dominar politica e militarmente o território nilótico. Internamente, os poderosos cleros de Amon e de Osíris lutam com o poder real, tentando manter as suas influentes posições administrativas no Egipto. O jovem 
faraó Ramsés apresentado pelo filme luta, desde príncipe, em duas frentes: militarmente contra os Assírios e internamente contra os sacerdotes para poder começar a guerra. O faraó acaba por ser morto e o país passa a ser controlado politicamente pelos sacerdotes.

Neste filme, rodado no deserto de Kisil-Kim, no Uzbequistão, entre Junho e Outubro de 1964, e durante algumas semanas no Egipto, com um elenco (George Zelnik, Barbara Brylska, Krystyna Mikolajewska, Andrzej Girtler, Ewa Krzyzewska, Piotr Pawloski, Leszek Herdegen, Jersy Buczacki) e uma equipa técnica completamente desconhecidos na cena internacional, o realizador polaco apresenta um alegórico confronto entre a classe sacerdotal egípcia e o poder civil, num claro eco dos conflitos entre a Igreja e o Estado polacos. Em 1966, o filme foi nomeado para os óscares na categoria de "Melhor Filme Estrangeiro", que acabaria por ser entregue ao filme checo Obchod na korze ( $A$ Loja da Rua Principal) de Jan Kádar e Elmar Klós.

Embora se reconheça a atenção posta nos pormenores das técnicas e utensílios militares da época (carros de guerra, lanças, escudos, adagas, machados de vários tipos) e nas insígnias de poder ostentadas pelo faraó egípcio (coroa decheret, ceptros hekat e nekhakha), historicamente, além da inexistência de Ramsés XII e de Ramsés XIII na XX dinastia da história egípcia, também a Assíria não era naquela época uma grande potência, nem os banqueiros fenícios, judeus ou gregos a que o filme faz alusão tiveram qualquer papel na vida da época. Da mesma forma, não era o talento que se usava como meio de pagamento às anacrónicas tropas fenícias e gregas, não sendo, de todo, a economia da época de feição monetária como o filme propõe ${ }^{(5)}$.

Em todos estes casos, estamos no domínio das ficções históricas, de leituras cinematográficas da história, de recriações acentuadamente românticas e fantasistas, onde se cruzam muitas opções políticas, ideológicas, históricas, estéticas, artísticas, etc. (resultantes do ambiente político-social-cultural da época em que o filme foi produzido e realizado, dos eventuais condicionalismos - orçamentais ou outros com que se tenha debatido, com o posicionamento artístico e liberdade criadora do realizador, com aspectos técnico-materiais associados às produções, com os traços de carácter e marcas de personalidade dos artistas, com episódios da vida artística e pessoal dos actores e actrizes envolvidos, etc.), que, não obstante, moldam, por vezes indelevelmente, a nossa própria visão do passado recriado nesses filmes e até a nossa própria capacidade de recriação desse passado. 
Estes filmes enfatizam, talvez excessivamente, as similaridades entre a cultura do século $X X$ e o mundo antigo para provar e mostrar que os antigos eram "como nós". Ao inserir as suas próprias construções políticas e sociais nas recriações de culturas passadas, os produtores/realizadores/estúdios afirmam aquilo que previamente as audiências já aceitaram ou que precisavam aceitar.

Nem sempre, ou mesmo quase nunca, há nestes filmes a intenção de pôr em cena ou de trabalhar com determinada(s) versão(ões) historiográfica(s). Não raro, cede-se ao mito, às re-elaborações produzidas pelo devir histórico. O objectivo é frequentemente apenas «mostrar", num ambiente de plausibilidade, verosimilhança e algum encanto, o passado, mesmo quando os erros históricos e os anacronismos mais ou menos flagrantes de todos os tipos se sucedem (por exemplo, os fechos éclair nas vestes antigas). Naturalmente, o estabelecimento de rigorosas relações causais e de correctas (científicas) linhas de interpretação e explicação não são objecto de trabalho aprofundado. Estamos perante filmes (de Hollywood e de outros quadrantes) e não de documentários históricos.

Algumas propostas procuram, no entanto, ler (construir ou reconstruir) o passado de uma forma pelo menos "visualmente correcta». A história é o ponto de partida, mas não necessariamente o ponto de chegada. A leitura cinematográfica confere um sentido (não o sentido).

Cada realizador ou estúdio, possuindo e trabalhando com um quadro de verosimilhanças possíveis (guarda-roupa, diálogos, linguajares, expressões fisionómicas, posturas corporais, lugares históricos, etc.), propõe a sua própria reconstituição verosímil do passado e influencia dessa forma a própria re-construção da verosimilhança dos espectadores/do público(6). Mais: o próprio filme de fundo histórico, como ficção histórica ou leitura cinematográfica da história antiga, é também uma construção que, como qualquer outra fonte, deve ser tomada de forma crítica, desconfiada até.

O que é verosímil ou a procura da verosimilhança de um autor/ /realizador/actor não corresponde obrigatoriamente aquilo que de facto aconteceu - tal desiderato é procurado no campo da História - nem aquilo que devia efectivamente ter acontecido - isso compete à ciência, entendida em sentido lato -, mas simplesmente aquilo que o público crê ser possível e que, em muitas situações, pode ser bem diferente do real histórico e do possível científico. Esta estética do público constitui um fértil campo para as propostas cinematográficas, por mais díspares ou concorrentes que sejam. Não raro, no imaginário do público, 
determinado actor ou determinada actriz, com as várias peripécias que assume na tela, sobrepõe-se à personagem histórica que interpreta; este passa a ser visto através daquele; este passa a ser aquele.

Isto deve-se, em parte, ao facto de a verosimilhança ser uma qualidade depositada no espírito humano através dos contributos (de diferente valor e calibre) da tradição, da informação, da opinião especializada ou até da simples opinião comum. É uma regra difusa com aparência de rigorosa. É uma regra razoável repleta de ambiguidades e subjectividades.

Cada obra cinematográfica, independentemente do seu objectivo ou do sucesso de bilheteira, é uma interpretação; parte de um modelo psicológico específico e concreto que é o do realizador, e, no limite, quando o filme se fixa no imaginário dos espectadores, transporta em si o gérmen capaz de produzir outras (novas) interpretações. Das sintonias (ou falta delas) estabelecidas pode resultar maior ou menor verosimilhança e pode mesmo derivar uma relativa objectividade da proposta fílmica. No fundo, a leitura cinematográfica pode ser uma paráfrase de um argumento escrito base, mais profunda ou superficial, mais simples ou criptada, mas sempre uma coisa outra que não uma simples tradução. O importante é mais a significação, a lógica da significação.

A indústria e o marketing cinematográficos têm procurado, todavia, maximizar as suas produções sobre temáticas históricas rotulando-as de "épicas", "históricas", "religiosas" ou "musicais", possuindo cada uma destas categorias uma carga de verdade, autenticidade e legitimidade que posicionam a proposta e moldam a concepção do espectador. A distribuição dos filmes por estas categorias é também uma forma de os aproximar (ou afastar) da matriz literária ou historiográfica de referência e, por isso, de fazer entrar em jogo as vertentes, de malha mais aberta ou mais fechada, da objectividade e da inteligibilidade.

Ao historiador da Antiguidade e ao professor cabe adoptar uma atitude simultaneamente aberta (o cinema de carácter histórico existe e não se pode escamotear o seu efeito na "preparação" do público comum e mesmo nos estudantes de nível superior) e ponderada (as películas "históricas" não podem reflectir exactamente todos os factos e os conhecimentos científicos existentes sobre determinada personagem ou época histórica). Em vez da desconfiança cega em relação a estas produções, devido aos "erros e omissões" e à "falsificação", deve, por um lado, reconhecer que a reconstrução totalmente fidedigna do passado é uma impossibilidade, por outro, entender o "cinema histórico" no quadro das suas próprias «leis» internas e considerar 
essas reconstituições, por mais livres que possam surgir, como ferramentas para um posterior trabalho de análise.

Ao mesmo tempo, o historiador não deve limitar-se a denunciar a falta de fiabilidade dos filmes históricos ou a reclamar a participação mais activa de historiadores profissionais nas equipas técnicas das películas. Deve antes reconhecer que, com uma outra finalidade, os filmes históricos contribuem para melhorar a visão figurada do passado antigo, embora por vezes de forma irracional, face a uma visão científica frequente e excessivamente fossilizada ou distorcida, embora mais racional. São, por isso, materiais complementares do conhecimento do passado.

Em causa podem estar sempre a forma como é feita a reconstrução desse passado; que significado e objectivos superintendem ou podem superintender a essas recriações; que relação se pode estabelecer entre os dados apresentados nas películas e aqueles que se conhecem através de outros meios e processos. É aqui, no fundo, que intervém a exegese histórica, apostada em clarificar as diferenças entre realidade cinematográfica e realidade, entre cinema histórico e História.

\section{Cleópatra no cinema ${ }^{(7)}$}

Cleopatra, de 1963, com 243 m., produzido por Walter Wanger para a $20^{\text {th }}$ Century Fox, realizado por Joseph Leo Mankiewicz ${ }^{(8)}$, com um guião assinado pelo próprio Mankiewicz, por Ranald MacDougall e Sidney Buchman, música de Alex North e interpretado, entre outros, por Elisabeth Taylor (Cleópatra), Richard Burton (António) e Rex Harrison (César) ${ }^{(9)}$, é um filme megalómano que goza de um lugar muito especial na galeria dos filmes-mito, embora, objectivamente, a película não tenha tido na época nem o êxito nem o retorno de bilheteira esperado, sobretudo quando comparado com o rotundo êxito comercial da Metro com o Ben-Hur de 1959.

Esta é, porém, uma vertente em que as opiniões não coincidem: para muitos, a ideia do fracasso comercial não é verdadeira, pois mesmo com o elevado orçamento o filme conseguiu recuperar ao longo dos anos o dinheiro nele investido, tornando-se, ao invés, um dos filmes mais bem sucedidos da década de 60 .

Do ponto de vista artístico, o filme é, de certa forma, desequilibrado, sustentando-se mais pelas suas virtudes técnicas do que pelas suas qualidades narrativas, alternando nas suas quatro horas cenas geniais e inesquecíveis com fastidiosas quebras de ritmo. Isso não impediu que tivesse ganho quatro óscares em 1964, para as categorias 
"Melhores Efeitos Especiais", "Melhor Fotografia", "Melhor Guarda-Roupa" e "Melhor Direcção de Artistas". Foi ainda indicado em cinco outras categorias, a saber, "Melhor Filme", "Melhor Actor" (Rex Harrison), "Melhor Edição", "Melhor Banda Sonora" e "Melhor Som».

O filme recebeu ainda quatro indicações para o Globo de Ouro, nas categorias de "Melhor Filme - Drama", "Melhor Realizador", "Melhor Actor - Drama" (Rex Harrison) e "Melhor Actor Secundário" (Roddy McDowall).

O filme de Joseph Mankiewicz foi a mais cara produção até à sua época, com uma verba total de cerca de 44 milhões de dólares (só Elizabeth Taylor arrecadou 7 milhões de dólares $\left.{ }^{(10)}\right)$. Só em 1997 o filme da Century Fox seria destronado nesta categoria do "mais caro de sempre" pelo filme Titanic. Não foi, todavia, o primeiro filme sobre Cleópatra.

De facto, na filmografia significativa sobre a última rainha dos Lágidas temos de recuar até ao século XIX, até 1899, para encontrarmos Cléopâtre, o primeiro filme sobre esta notável personagem histórica. Trata-se de um curto filme mudo de terror (um dos primeiros do género), a preto e branco, sobre a ressurreição da múmia de Cleópatra, escrito e dirigido pelo pioneiro francês Georges Méliès. Nele é possível ver a profanação do túmulo da rainha, a sua múmia a ser queimada, surgindo do fumo produzido uma Cleópatra divina, imortai: a actriz francesa Jeanne d'Alcy, a primeira actriz a representar o papel de Cleópatra no cinema, no caso apenas durante dois minutos. Durante muito

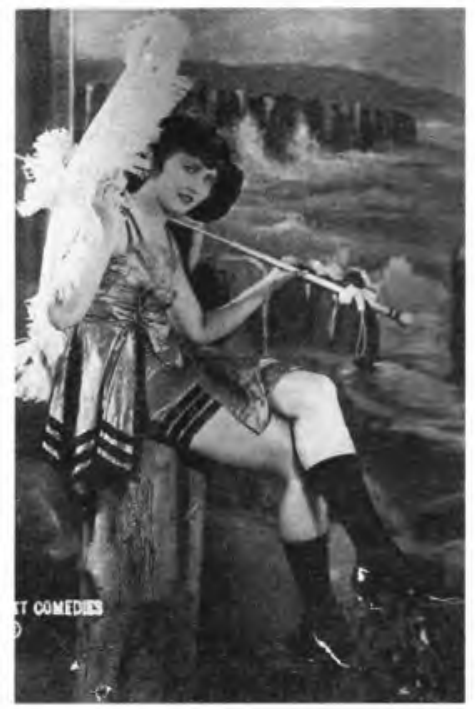

A francesa Jeanne d'Alcy (1865-1965), que se tornaria na primeira Cleópatra no cinema 
tempo considerou-se que este mini-épico se tratava de um «filme perdido" até que uma cópia foi encontrada em Paris, em 2005.

Antes de 1914, na era do cinema mudo, a França continuou à frente das produções de filmes sobre Cleópatra com mais quatro filmes, sendo os mais significativos da autoria de Henri Andréani (1877-1936), Ferdinand Zecca (1864-1947) e Louis Feuillade (1873-1925), até que os Americanos, em 1908, fascinados também pela personagem da antiga governante do Egipto, efectuaram a primeira adaptação para o cinema da peça Antony and Cleopatra de William Shakespeare, dirigida pelos realizadores James Stuart Blackton e Charles Kent e contando no elenco com Florence Lawrence, Maurice Costello e William Rnus.

Nos Estados Unidos, em 1911, Theo Frenkel realiza The passions of an Egyptian Princess, com Julie Meijer no papel de Cleópatra. Produzido em cinemacolor, centra-se, como o próprio nome sugere, nas paixões da última rainha do Egipto, designadamente pelos dois homens fortes dos dois triunviratos romanos: Júlio César e Marco António.

Também nos Estados Unidos, em 1912, Charles L. Gaskill dirige a esposa Helen Gardner em Cleopatra, um outro filme mudo a preto e branco, com $88 \mathrm{~m}$, que se considerou um filme de topo na época. Gaskill adaptou a peça de Victorien Sardou, estreada em Paris em 1890. Do elenco faziam também parte Charles Sindelar (Marco António), Pearl Sindelar (Iras), Miss Fielding (Charmion), Miss Robson (Octávia) e Harley Knoles (Khefren, capitão da guarda da rainha). Este registo fílmico, devido ao papel da actriz principal que era também editora, responsável pelo guarda-roupa e membro da produtora, é também conhecido como Helen Gardner in Cleopatra.

O filme conta a história do encontro entre Cleópatra e Marco António, em Tarso (Sul da Anatólia), sob a acusação de conspiração, com o qual se inicia o romance entre os dois. A narração cinematográfica acompanha o regresso de Marco António a Roma, depois da morte da sua esposa Flávia, por razões políticas, onde celebra casamento com Octávia, a irmã de Octávio, o companheiro de triunvirato de Marco António, bem como a batalha de Áccio, do ano 31 a. C., e a morte dos dois amantes em Alexandria. Cleópatra suicida-se colocando uma áspide sobre o seu peito.

Em 1913 caberá ao italiano Enrico Guazzoni, um dos maiores realizadores do cinema mudo, assinar Marcantonio e Cleopatra, num magnífico trabalho de reconstituição histórica a partir de uma adaptação da peça de Shakespeare (da autoria de Pietro Cossa), em que os papéis principais são entregues a Gianna Terribili-Gonzales (Cleópatra) 
e Giuseppe Piemontesi (Marco António). Integravam também o elenco Ida Carloni Talli, Bruto Castellani e Matilde Di Marzio.

A história dos amores do triúnviro e da rainha do Egipto é contada no contexto da grande história e conquista do Mediterrâneo por Roma, apostando nos elementos exóticos e majestosos dos cenários egípcios. Grande êxito de público, o filme de Guazzoni conjugava erotismo, exotismo, beleza feminina e intriga histórica ${ }^{(11)}$.

Quatro anos depois, em 1917, surge a Cleopatra, com 125 m, do realizador J. Gordon Edward, baseado no romance de Rider Haggard. Filme mudo a preto e branco tem no papel de protagonista a actriz Theda Bara (nome artístico de Theodosia Goodman), uma das mais populares actrizes do cinema mudo da sua época. Entre os actores, contavam-se também Fritz Leiber (Júlio César), Thurston Hall (Marco António), Dorothy Drake (Charmion), Delle Duncan (Iras) e Henri De Vries (Octávio).

O papel de Theda Bara (cujo nome é um anagrama de "Arab Death"), como uma lânguida e sedutora Cleópatra, cheia de sensualidade e exotismo, com a enorme variedade de faustosos e sensuais vestidos e adereços e depois outros papéis de femme fatale, granjearam-Ihe a alcunha de "The Vamp». Para muitos estudiosos da história do cinema, Theda Bara foi a primeira sex symbol dos ecrãs, a primeira vamp da história do cinema ${ }^{(12)}$. A sua interpretação de Cleópatra ajudou a difundir durante anos uma imagem exótica do Egipto e da sua última rainha. Pode mesmo dizer-se que o filme de 1917 foi uma das primeiras e mais notáveis reconstituições do mito da rainha egípcia e do antigo Egipto ${ }^{(13)}$.

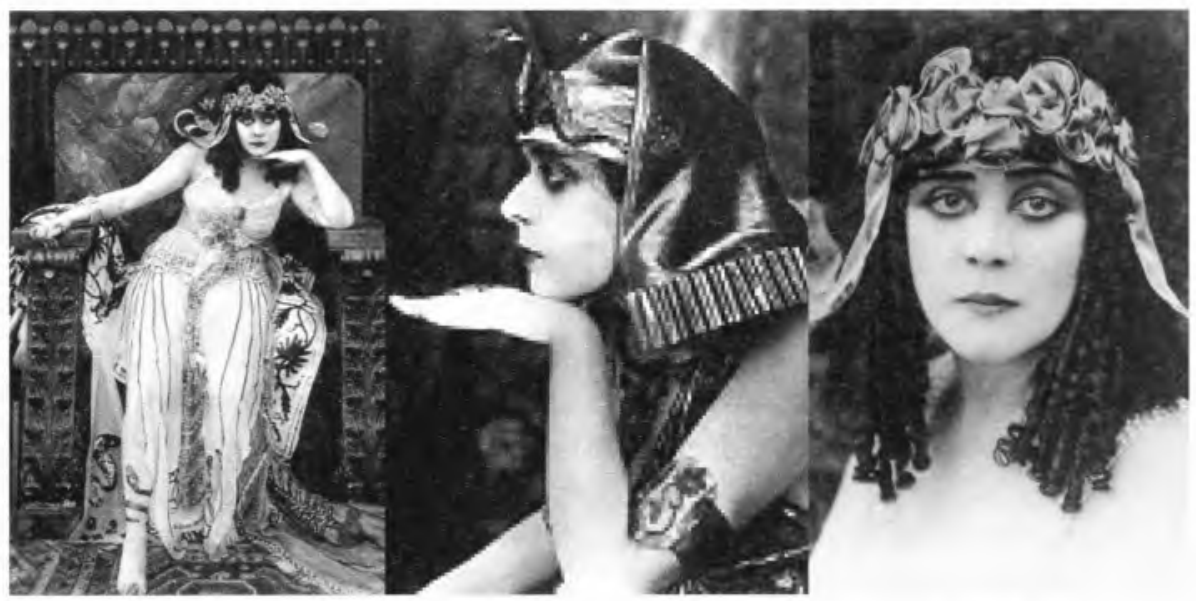

Theda Bara (1885-1955), “The Vamp», como Cleópatra, em 1917. 
Com a imposição do Código Hays, o filme de Gordon Edward foi considerado obsceno e as duas últimas cópias conhecidas foram queimadas nos estúdios Fox e no Museum of Modern Art, em Nova lorque. Só sobreviveram alguns fragmentos.

Esta Cleopatra de 1917, muito perto também da peça Antony and Cleopatra de William Shakespeare, foi um dos mais elaborados filmes realizados em Hollywood até essa altura e um dos que maior

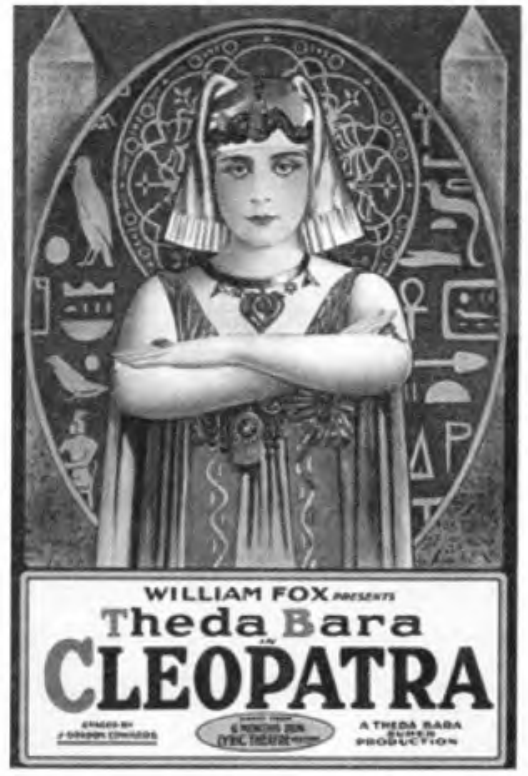
sucesso obteve até então. De acordo com o estúdio, o filme custou meio milhão de dólares e foram usados mais de 2000 figurantes em determinadas cenas.

Os anos vinte, sobretudo nos Estados Unidos da América, mas também na Alemanha, foram marcado por vários filmes sem expressão cinematográfica substantiva sobre Cleópatra. De facto, foi preciso esperar cerca de vinte anos para encontrar um filme e uma actriz capaz de rivalizar com o Cleopatra de Gordon Edward/Theda Bara: o épico de Hollywood da Paramount Studios com o mesmo título, Cleopatra, a preto e branco, de 1934.

Com 100 minutos, foi escrito por Waldemar Young e Vincent Lawrence com base no material histórico adaptado por Bartlett Cormack e produzido e dirigido por Cecil B. de Mille, um director que tinha uma grande paixão pelo género histórico, com Claudette Colbert no papel principal, Warren Williams como César, Henry Wilcoxon como Marco António, Joseph Schildkraut no papel de rei Herodes e de lan Keith como Octávio(14).

Esta realização de Cecil $\mathrm{B}$. de Mille é considerada o melhor de todos os filmes sobre Cleópatra, tanto ao nível do argumento como da encenação. Os sumptuosos cenários art deco (de Hans Dreier), o sensualmente sugestivo guarda-roupa das personagens femininas (de Travis Banton) e a música de Rudolph Kopp estão também entre os aspectos que catapultaram este filme para a categoria de filme clássico.

Embora nomeado para os prémios da Academia de 1935 nas categorias de "Melhor Filme» (o vencedor foi a comédia romântica 
It/Happened One Night, de Frank Capra e Harry Cohn, onde Claudette Colbert era também a protagonista), "Melhor Assistente de Realização" (Cullen Tate), "Melhor Montagem" (Anne Bauchens) e "Melhor Som" (Franklin Hansen), Cleopatra só arrecadaria o prémio para "Melhor Fotografia" (Victor Milner).

O forte carácter e a forte personalidade, empreendedora e independente, da actriz escolhida para dar corpo a Cleópatra não só se conjugavam bem com a imagem da mulher americana liberada dos anos 20 e 30 como com a imagem entretanto criada e difundida pelo cinema sobre a Cleópatra VII.

Entre as mais famosas cenas desta grande epopeia de De Mille destaca-se a cena da sedução de António no barco real de Cleópatra, que se tornou numa das imagens-símbolo do filme, com a sua procissão das bailarinas semi-nuas, as bebidas e os alimentos exóticos do jantar. Claudette Colbert imprimiu à sua interpretação uma considerável carga de sensualidade, exotismo e beleza que fazem desta reconstituição uma imagem de marca da cinematografia sobre Cleópatra. Paralelamente, o realizador procurou alcançar o rigor histórico possível, na recriação dos ambientes do antigo Egipto helenístico.

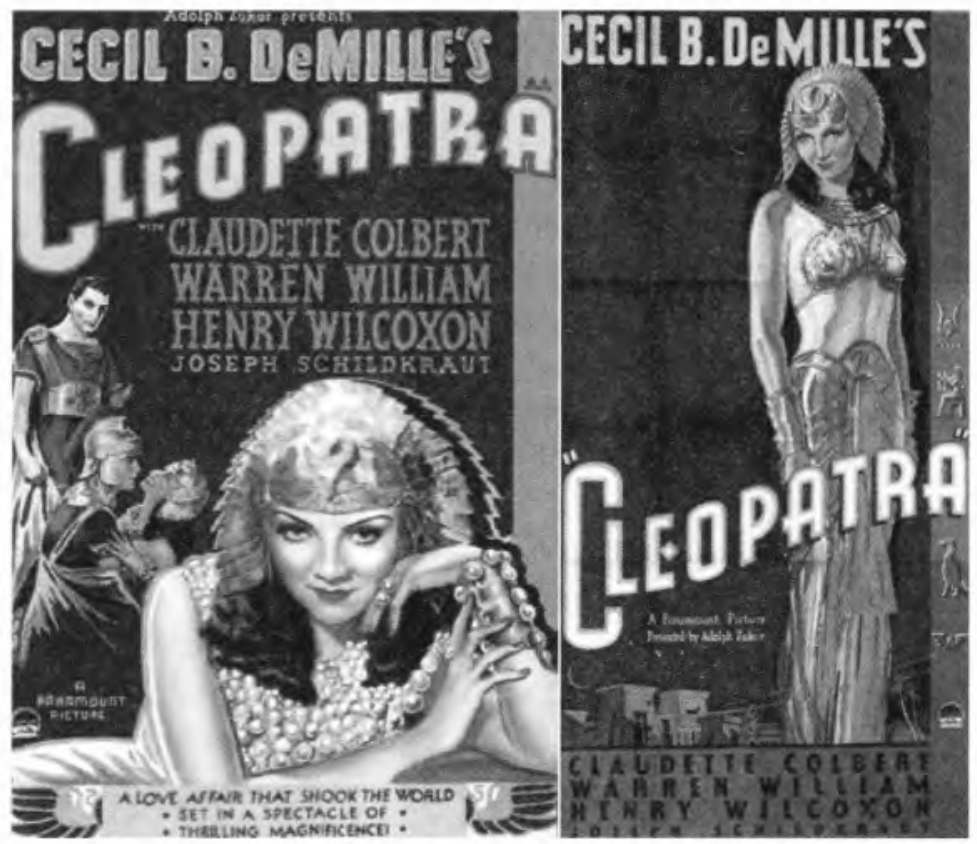

Claudette Colbert (1903-1996), a Cleópatra de Cecil B. de Mille, em 1934. 
Em 1945 seria a vez de Vivian Leigh encarnar a rainha egípcia em Caesar and Cleopatra $(123 \mathrm{~m})$. Escrito por George Bernard Shaw (última versão de uma peça sua feita e autorizada em vida, uma vez que o autor morreria volvidos cinco anos, em 1950), dirigido e produzido por Gabriel Pascal, o filme integrava no elenco,

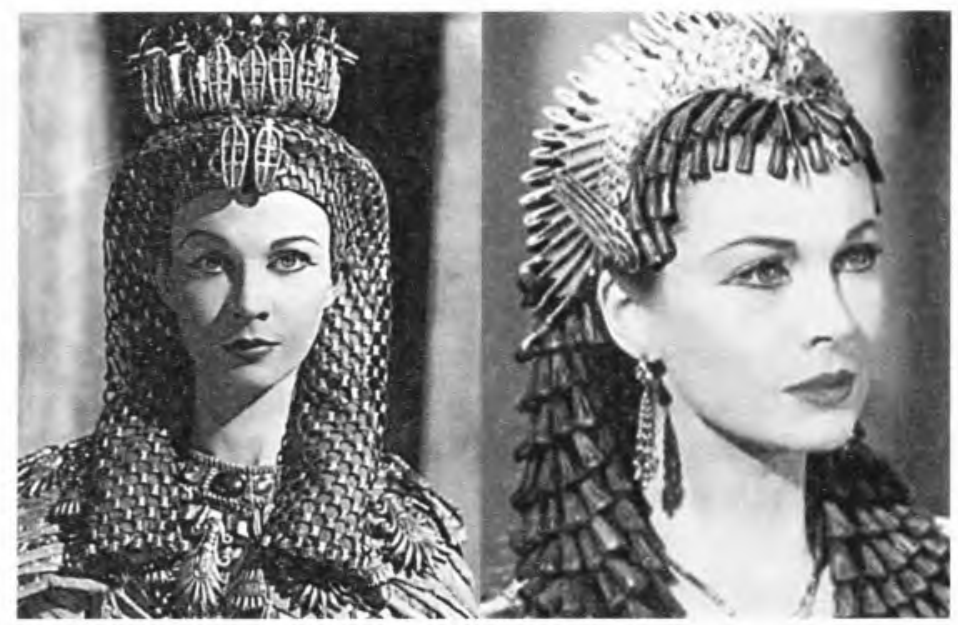

Vivian Leigh (1913-1967) encarnando Cleópatra em Caesar and Cleopatra (1945).

entre outros, além de Vivien Leigh, Claude Rains (Júlio César), Stewart Granger (Apolodoro), Francis L. Sullivan (Potínio), Basil Sydney (Rufio) e Cecil Parker (Britânio). A personalidade conflituosa de Vivian Leigh é frequentemente referida como justificação para um

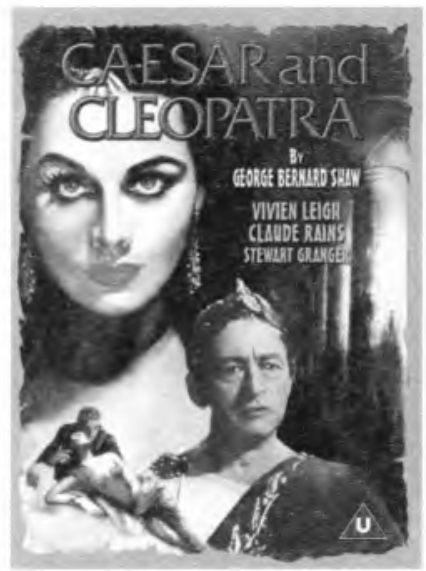
desempenho "menos conseguido" na pele de Cleópatra ${ }^{(15)}$. O filme foi nomeado para a categoria de "Melhor Direcção Artística" (John Bryan) de 1946, ano em que o prémio foi a entregue a Cedric Gibbons, Paul Groesse e Edwin B. Willis pelo filme The Yearling.

Centrado no relacionamento político-amoroso entre Júlio César e Cleópatra, o filme em technicolor incluía luxuriosas cenas, sendo considerado a produção mais cara jamais feita na Grã-Bretanha. 
Antes do clássico de Taylor e Burton, de 1963, houve ainda vários filmes menores sobre Cleópatra. Merecem, todavia, ser referenciados três: um de 1943, Cleobatra, em árabe, com realização de Ibrahim Lama e com a actriz Amina Rizk no papel de Cleópatra, e dois outros de 1953: uma comédia italiana intitulada Due notti con Cleopatra (78 m),

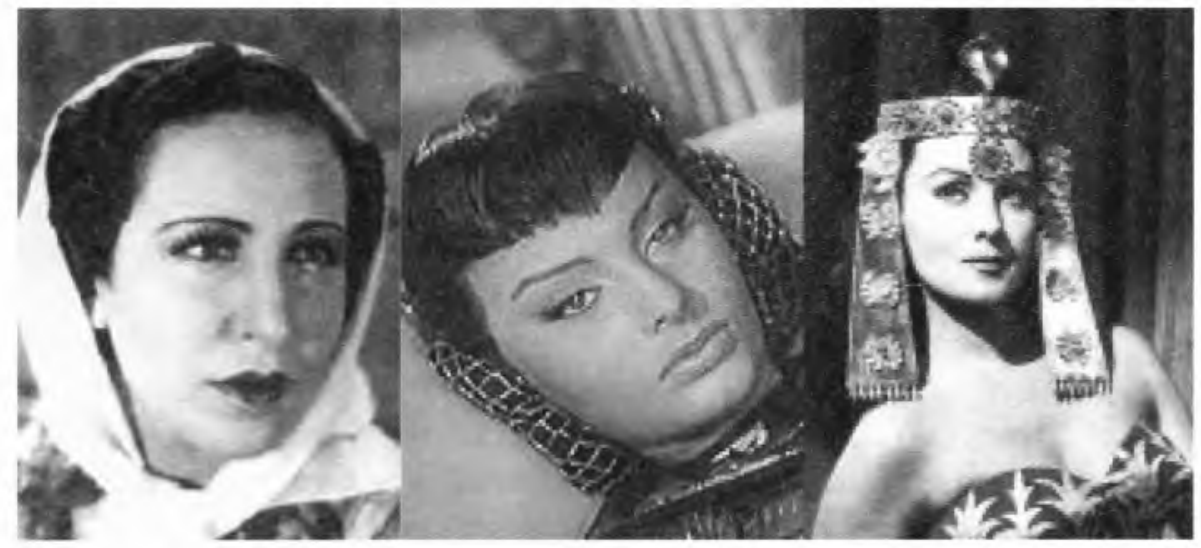

Amina Rizk (1910-2003), a artista de cinema egípcia que fez de Cleópatra em 1943,

Sophia Loren (1934- ...) encarnando a rainha do Egipto, em 1953

e Rhonda Fleming $(1923$ - ...), outra Cleópatra de 1953

realizado por Mario Mattol, com Sophia Loren e Alberto Sordi, e outro americano, Serpent of the Nile $(81 \mathrm{~m})$, com Raymond Burr (Marco António), Rhonda Fleming (Cleópatra), William Lundigan (Lucílio) e Michael Fox (Octávio) no elenco, Sam Katzman na produção e William Castle na realização. No primeiro, Sophia Loren é a Cleópatra por quem os homens dão a vida para passar uma noite. No segundo, o papel foi atribuído a Rhonda Fleming, a «rainha do technicolor».

O ano de 1959 regista uma produção franco-italiana-egípcia intitulada Le Legioni di Cleopatra, com realização de Vittorio Cottafavi, tendo nos principais Linda Cristal (nome artístico de Marta Victoria Moya Burges), Ettore Manni e Georges Marchal.

A argentina Linda Cristal $(1934$ - ...) que foi Cleópatra em Le Legioni di Cleopatra, em 1959.

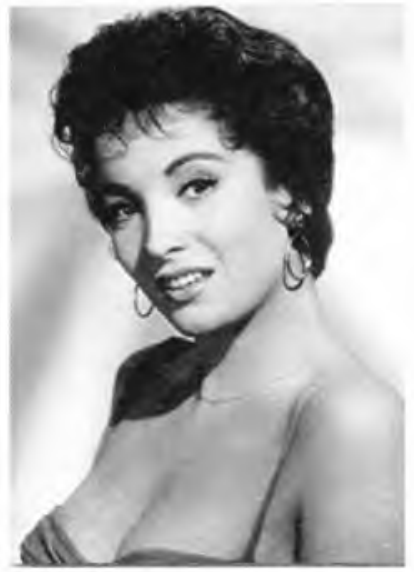


Cada uma à sua maneira, dentro dos limites impostos pela difusão dos filmes, na razão directa da importância e do peso dos estúdios produtores, dos seus realizadores e dos elencos constituídos, todas as actrizes escolhidas para interpretar o papel de Cleópatra foram instalando progressivamente no imaginário colectivo de milhões de espectadores a imagem da última rainha do Egipto e dos seus complexos jogos de poder com os líderes romanos do seu tempo.

Mas seria Elizabeth Taylor a fixar definitivamente essa imagem, com a sua performance de 1963, nomeadamente ao lado de Marco António/Richard Burton. Elizabeth Taylor, ídolo do cinema americano dos anos 60 , com os seus olhos de um profundo azul com tons violeta, deu realmente rosto e corpo a uma convincente Cleópatra que para muitos se passou a conceber e visualizar com o aspecto da diva americana. A Cleópatra de E. Taylor reinventou a antiga figura histórica. A sua interpretação permite percepcionar a personalidade complexa e contraditória de uma rainha e mulher que se movia perigosamente entre os impulsos da paixão amorosa-sexual e os interesses políticos e diplomáticos do reino do Egipto e da República romana.

O trágico destino de Cleópatra e de Marco António, cuja paixão foi paga com a própria vida, tiveram no filme de Mankiewicz um forte e inesperado aliado de atracção junto das audiências: a ligação amo-

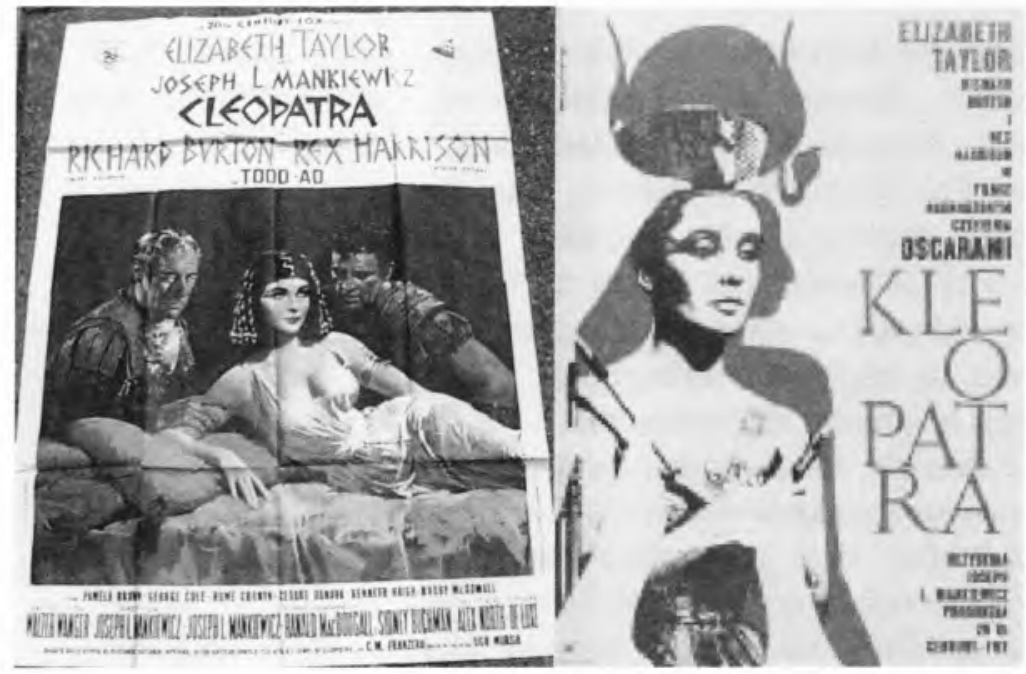

Poster de Cleopatra (58 x $84 \mathrm{~cm}$; offsef) da autoria do designer Eryk Lipinski: hierática silhueta de Elizabeth Taylor com uma sombra em fundo que representa a deusa egípcia ísis, com quem a histórica Cleópatra se identificava do ponto de vista cultual, político e até pessoal. 
rosa de Taylor e Burton durante as filmagens. Paixão, amor e romance conjugaram-se de forma única nesta Cleopatra de 1963 e ajudaram a elevar e a confundir o mito, a história romântica e a História.

Razão tinha o produtor Walter Wanger ao escolher Elizabeth Taylor para o papel de Cleópatra em vez de outras fortes candidatas

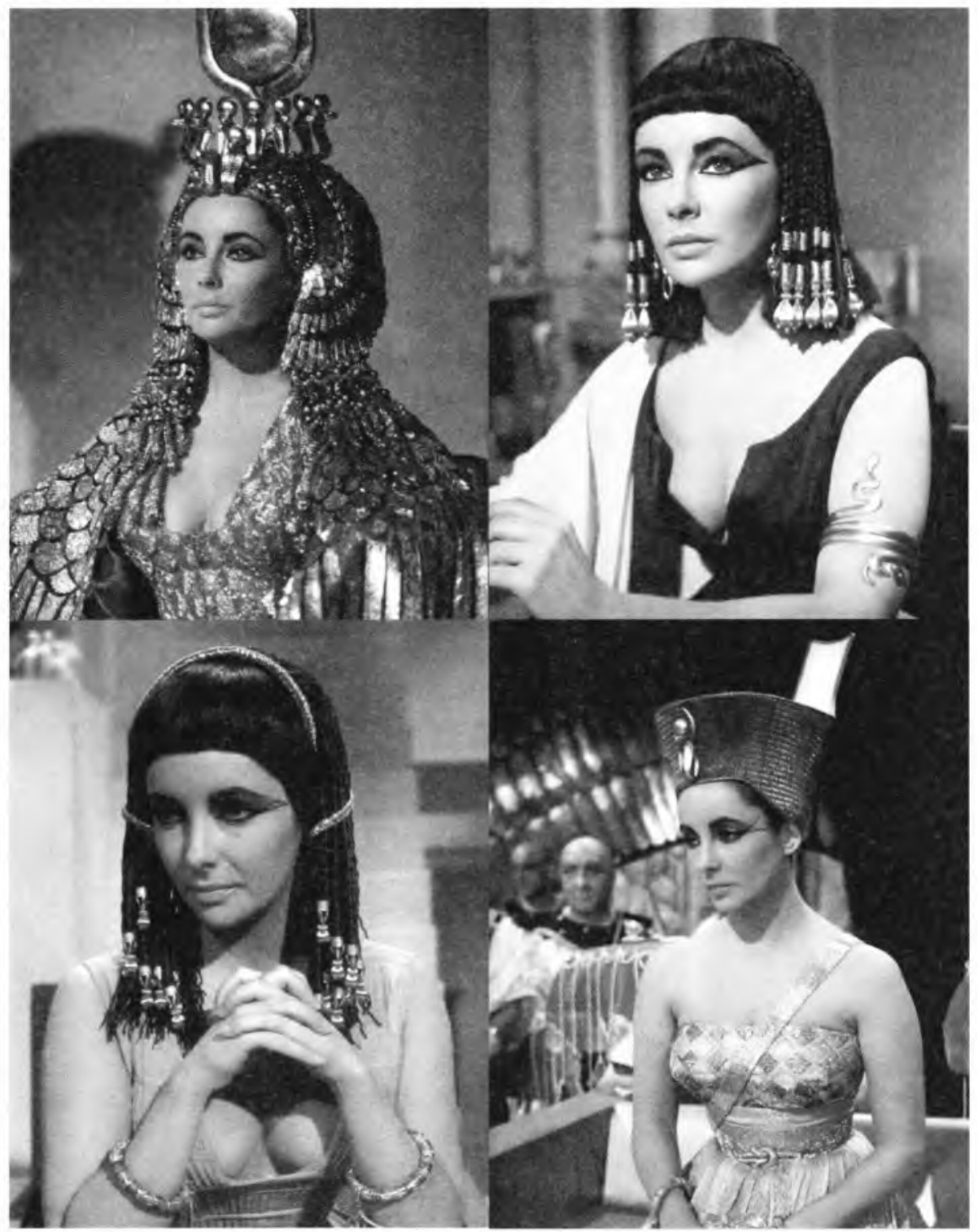

Elizabeth Taylor (1932 - ...) numa inesquecivel e marcante Cleópatra, em 1963. 
como Susan Hayward, Marilyn Monroe, Brigitte Bardot e Sophia Loren. Como ele sustentou na altura, Elizabeth Taylor era "a única estrela com a juventude e a emoção necessárias ... uma das mulheres mais maravilhosas do nosso tempo, uma verdadeira Cleópatra moderna.»

À popularidade, beleza, luxo e poder de Elizabeth Taylor acrescentou-se, portanto, o facto de ter conhecido o galês Richard Burton durante a rodagem. Ambos casados nessa altura, vivem um escaldante e escandaloso romance, muito criticado por irritados puritanos que não hesitam em verberar publicamente os adúlteros ${ }^{(16)}$, ampliado ainda mais pelo facto de Eddie Fisher (o então marido de Elizabeth Taylor) e a mulher de Burton se recusarem a dar-lhes o divórcio, obrigando a dupla apaixonada a viver o seu grande amor "clandestinamente».

O casal (considerado por muitos amantes da sétima arte como "O casal do século») acabará por casar, pela primeira vez, em 15 de Março de 1964, em Montreal. Inicia-se uma parceria no ecrã e na vida de cerca de dez anos (dez filmes juntos ${ }^{(17)}$ ). Taylor e Burton acabarão, contudo, por se separar (26 de Junho de 1974) para voltarem a casar na África do Sul, a 10 de Outubro de 1975. Novo divórcio ocorrerá menos de um ano depois, a 29 de Julho de $1976^{(18)}$.

A história de Cleópatra e de Marco António que Elizabeth Taylor e Richard Burton corporizam é uma clara e assumida demonstração

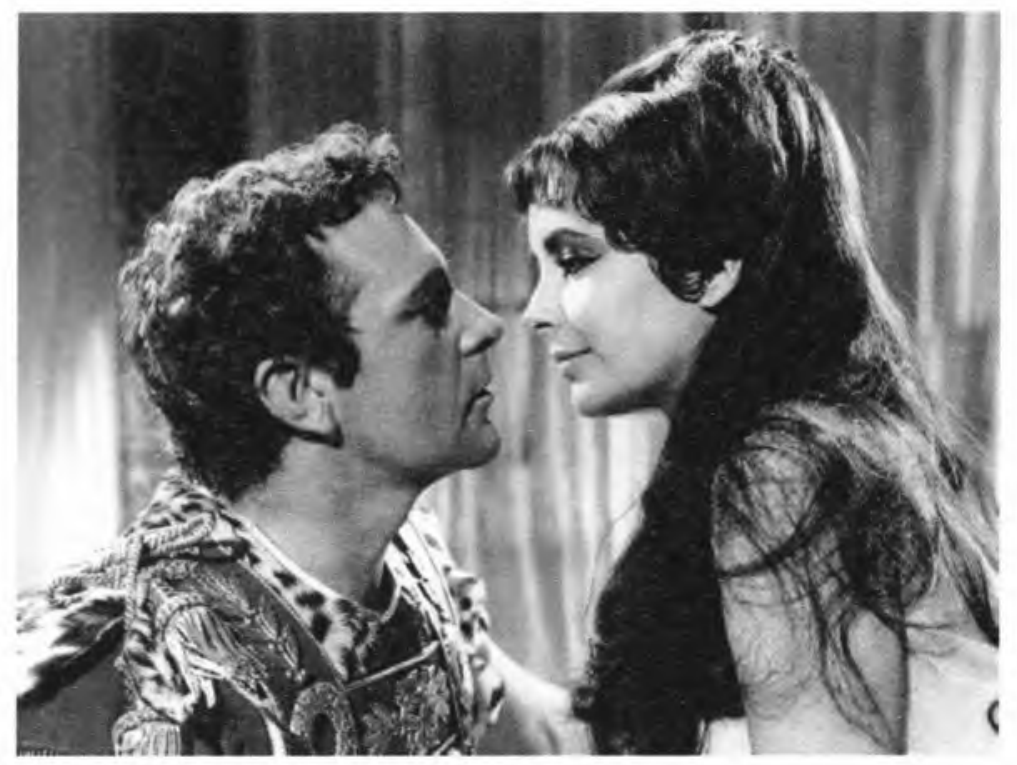

Richard Burton e Elizabet Taylor como Marco António e Cleópatra. 
da influência da política no amor (e vice-versa) e de como a projecção desse topos no grande ecrã pode fascinar e marcar indelevelmente á própria leitura do passado histórico. A personalidade exuberante e poderosa de Elizabeth Taylor e a sua imagem forte, sensual e sexualmente agressiva colam-se particularmente bem ao papel de Cleópatra e a rainha egípcia reconfigura-se com esses traços no imaginário das audiências. Personagem e actriz misturam-se, confundem-se.

A espectacularidade cinematográfica (cenários, figurinos ${ }^{(19)}$ e miIhares de figurantes) e duração das gravações desta superprodução histórica (três anos, de 1960 a 1963), agravadas pelos problemas de saúde e pelos caprichos da estrela principal, provocaram uma enorme derrapagem financeira que acabaram por levar à quase ruína da Century Fox e de Joseph Mankiewicz. Devido aos numerosos escândalos e problemas financeiros, o filme foi terminado em Almeria (Espanha), onde se rodaram designadamente as cenas iniciais do filme referentes ao desenlace da batalha de Farsália. Ainda assim, a Cleopatra de Mankiewicz é considerado até hoje o último grande épico histórico custeado por um estúdio de Hollywood.

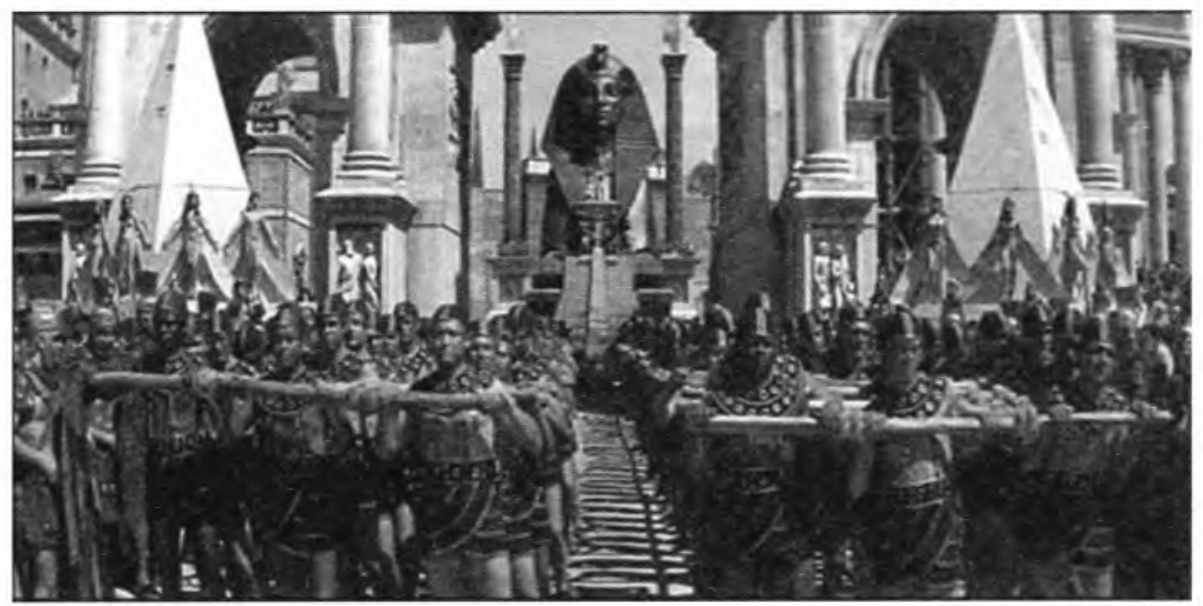

A espectacular cena da entrada de Cleópatra em Roma, puxada por centenas de homens, é uma das cenas-símbolo do filme de 1963.

Muitos, mais críticos e implacáveis, apelidam esta produção de Hollywood de "projecto ambicioso", "filme kitsch", "gigantesca mascarada", pouco realista, pomposa, extravagante, de eróticos idílios, repleta de chichés de todos os tipos, da temática (a procura do verda- 
deiro amor no meio da trama política) aos diálogos e cenários, passando pelo desenho da personagem de Cleópatra.

O certo, porém, é que a visão desta personagem e da sua intervenção na história do século I a. C. transmitida por este filme colaborou para acentuar os traços míticos associados à rainha egípcia. Quantos não imaginam, ainda hoje, Cleópatra sob os traços físicos e atitudinais de Elizabeth Taylor? E o mesmo é válido para outros personagens, para os ambientes, paisagens, monumentos, decorações...

\begin{abstract}
Notas
(1) Este texto deriva directamente do comentário presencial por nós efectuado do filme em questão, a 17 de Janeiro e a 14 de Fevereiro de 2009, no Museu Nacional de Arqueologia, no âmbito do programa «A Arqueologia no Cinema", em sessões promovidas pelo Grupo de Amigos do Museu Nacional de Arqueologia. Este texto será completado no próximo número da revista Cadmo com a II parte, onde se efectuará um comentário histórico detalhado do filme em apreciação. A bibliografia e webgrafia do texto serão disponibilizadas, como um todo, no final do texto da II parte.
\end{abstract}

(2) Cf. José das Candeias SALES, "Os épicos bíblicos das décadas de 50 e de 60 do século XX ou em torno das verosimilhanças e objectividades possíveis", in Susana Bastos Mateus e Paulo Mendes Pinto (orgs.), A Sétima Arte no Sétimo Céu. O Cinema e a Religião (prefácio de Frei Bento Domingues), Lisboa, Firmamento, 2005, pp. 21-25.

(3) Em 1959, Howars Hawks filmaria o seu terceiro grande épico do Oeste: Rio Bravo (Cf. Olivier-René Veillon, Dicionário de cinema americano - os anos cinquenta (1945-1960), Lisboa, Publicações Dom Quixote, 1985, p. 97).

(4) Cf. J. C. SALES, Poder e iconografia no antigo Egipto, Lisboa, Livros Horizonte, 2008, pp. 71-82.

(5) Cf. Alberto PRIETO, «Faraón", in José Uroz (ed.), Historia y Cine, Alicante, Publicaciones de la Universidad de Alicante, 1999, p. 85.

(6) Cf. J. C. SALES, ob. cit., pp. 71, 72.

(7) Para a elaboração dos elementos da filmografia mais significativa sobre Cleópatra até ao filme de Joseph Mankiewicz, usámos, sobretudo, Prudence J. JONES, Cleopatra. A sourcebook, Norman, University of Oklahoma Press, 2006, pp. 325, 326; Claude AZIZA, "Cléopâtre l'immortelle", in L'Histoire, n. ${ }^{\circ} 238$, Paris, Société d'Editions Scientifiques, Décembre 1999, p. 36; http://www.wepwawet.nl/films/ (26 Dez. 2008). Foram também compulsados: Georges SADOUL, Dictionnaire des cineastes (remis à jour par Emile Breton et Michel Marie en 1981), Paris, Seuil, 1965; Id., Dictionnaire des films (remis à jour par Emile Breton en 1981), Paris, Seuil, 1965, e Maurice BESSY, Jean-Louis CHARDANS, Dictionnaire du cinéma et de la télévision, Paris, 1965.

(8) O realizador inicial foi Rouben Mamoulian que começou a rodar o filme em Londres, onde se haviam construído três hectares de cenário, para, depois de Elizabeth Taylor ter adoecido com uma grave infecção (que, em Março de 1960, evolui para uma pneumonia que a deixa entre a vida e a morte, só se salvando com uma traqueotomia), se demitir (face a outros compromissos entretanto assumidos), cabendo a continuação do projecto a 
Joseph L. Mankiewicz, que assim ficou para sempre como o realizador desta superprodução. As companhias de seguro, impacientes com a doença de E. Taylor, propõem a sua substituição por Marilyn Monroe, mas a Fox insiste na actriz. Em Setembro de 1961, as filmagens são transferidas para Roma, para a Cinecitá, já sob a direcção de Mankiewicz, sendo os actores iniciais (Peter Finch como Júlio César e Stephen Boyd como Marco António) substituídos respectivamente por Rex Harrison e Richard Burton. As cicatrizes da traqueotomia de Elizabeth Taylor são visíveis em várias cenas do filme.

(9) O elenco completo incluía também Pamela Brown (sacerdotisa de Ísis), George Cole (Flávio, camareiro de Júlio César), Hume Cronyn (Sosígenes), Cesare Danova (Apolodoro), Kenneth Haigh (Brutus), Andrew Keir (Agripa), Martin Landau (Rúfio), Roddy McDowall (Octávio - César Augusto), Robert Stephens (Germânico), Francesca Annis (Iras, camareira de Cleópatra), Grégoire Aslan (Potino) e Martin Benson (Ramos).

(10) Inicialmente, o contrato de Taylor com a Century Fox foi fixado em um milhão de dólares, o que seria já a maior quantia paga a uma estrela até esse momento. No entanto, com os atrasos na produção, a actriz passou a ganhar horas-extras no valor de 50.000 dólares/semana. Os 44 milhões de dólares da época equivaleriam hoje à módica quantia de 400 milhões de dólares.

(11) Cf. Luís A. GARCIA MORENO, "Cleopatra. El film de Joseph L. Mankiewicz", in José Uroz (ed.), Historia y Cine, Alicante, Publicaciones de la Universidad de Alicante, 1999, p. 167.

(12) Cf. Maurice BESSY, Jean-Louis CHARDANS, Dictionnaire du cinéma et de la television - Tome I. A-B-C, Paris, 1965, p. 174.

(13) Veja-se "Theda Bara as Cleopatra - 1917 (Clean version)", 4.04 min., in http:// www.youtube.com/watch?v=IsqVSff84ZO (17 de Janeiro de 2009).

(14) Vide o filme em causa, dividido em 10 partes de 11 minutos cada, sob o título genérico "Cleopatra (1934)" in http://www.youtube.com/watch?v=WhUwm70Rir (1/10);

http://www.youtube.com/watch?v=ovLux_87cDI (2/10);

http://www.youtube.com/watch?v=A66xMer7LeA (3/10);

http://www.youtube.com/watch?v=ezT1jsFjkb4 (4/10);

http://www. youtube.com/watch?v=mDPxXfkcvCc (5/10);

http://www.youtube.com/watch?v=TRSaX2flhOc (6/10);

http://www.youtube.com/watch?v=Ggtnpm8FUsQ (7/10);

http://www.youtube.com/watch?v=H7S3-J8ZHMU (8/10);

http://www.youtube.com/watch?v=Zr5MOFTn4Yw (9/10);

http://www.youtube.com/watch?v=4qeeOVIKe7I (10/10).

(15) Ver "Vivian Leigh - The Queen of the Nile", 2.54 m., in http://www.youtube.com/ watch? $v=3$ cc2Gves $3 g E$.

(16) Um congressista americano da época chega a propor, por motivos morais, a proibição da sua entrada nos Estados Unidos. Um jornal do Vaticano acusou Elizabeth Taylor de ter descido ao nível da "vagabunda erótica".

(17) Os dez filmes em que o casal Taylor/Burton actuaram juntos, além de Cleopatra (1963), foram: The V.I.P.S (1963) de Anthony Asquith; The Sandpiper (1965) de Vincentte 
Minneli; Whos's Afraid of Viriginia Woolf? (1966) de Mike Nichols; The Taming of the Shrew (1967) de Franco Zeffirelli; Doctor Faustus (1967), dirigido pelo próprio Richard Burton; The Comedians (1967) de Peter Glenville; O Boom! (1968) de Joseph Losey; Anne of the Thousand Days (1969) de Charles Jarrott; Hammersmith is out (1972) de Peter Ustinov e Divorce His, Divorce Hers (1973) de Waris Hussein.

(18) Elizabeth Taylor é também famosa pelos seus oito casamentos com sete maridos, todos terminados em divórcio, à excepção do seu terceiro casamento que terminou com a morte do marido, Michael Todd. Os seus vários maridos foram Conrad "Nicky" Hilton (6 de Maio de 1950-29 de Janeiro de 1951), Michael Wilding (21 de Fevereiro de 1952-26 de Janeiro de 1957), Michael Todd (2 de Fevereiro de 1957-22 de Março de 1958), Eddie Fisher (12 de Maio de 1959-6 de Março de 1964), Richard Burton (15 de Março de 1964-26 de Junho de 1974 e 10 de Outubro de 1975-29 de Julho de 1976), John Warner (4 de Dezembro de 1976-7 de Novembro de 1982) e Larry Fortensky (6 de Outubro de 1991-31 de Outubro de 1996).

(19) A título de curiosidade, diga-se que só Elizabeth Taylor usou 65 fatos diferentes, incluindo um feito com ouro de 24 quilates. 